J. Clin. Chem. Clin. Biochem.

Vol. 19, 1981, pp. 1033-1038

\title{
Development of a Rat Urinary Kallikrein-Binding Radioimmunoassay and Identification of Homologous Enzyme in Plasma
}

\author{
By N. B. Oza \\ Evans Memorial Department of Clinical Research and Department of Medicine, University Hospital, \\ Boston University Medical Center, Boston, Mass.
}

(Received February 5/October 2, 1979/February 19, 1981)

Summary: A complete description of a component-binding radioimmunoassay of rat urinary kallikrein is presented. Each step of the radioimmunoassay was evaluated and optimized. The problems encountered in the development of the assay are discussed; this may be a guide to the treatment of similar problems in the development of a comparable component-binding radioimmunoassay. Protocols are presented for performance of the assay with [ $\left.{ }^{3} \mathrm{H}\right]$-labelled or $\left[{ }^{125} \mathrm{I}\right]$-labelled rat urinary kallikrein. Radioimmunoassay and immunodoublediffusion data suggested that rat plasma indeed contains an antigen similar to glandular kallikrein. However, quantitation of the antigen by the direct radioimmunoassay must await appropriate developments for efficient dissociation and/or denaturation of interfering substances.

\section{Radioimmunassay für Kallikrein in Rattenharn und Identifizierung des homologen Enzyms im Plasma}

Zusammenfassung: Ein komponentenbindender Radioimmunassay für Kallikrein in Rattenharn wird vollständig und ausführlich beschrieben. Jeder Schritt des Radioimmunassay wurde ausgewertet und optimiert. Die bei der Entwicklung der Bestimmung aufgetretenen Probleme werden diskutiert; dies kann eine Anleitung für die Behandlung ähnlicher Probleme bei der Entwicklung eines vergleichbaren komponentenbindenden Radioimmunassay sein. Protokolle für die Durchführung der Bestimmung mit ${ }^{3} \mathrm{H}$ - bzw. ${ }^{125} \mathrm{I}$-markiertem Kallikrein aus Rattenharn werden beschrieben. Daten des Radioimmunassay und der Immundoppeldiffusion weisen daraufhin, daß Rattenplasma wirklich ein dem glandulären Kallikrein ähnliches Antigen enthält. Die quantitative Bestimmung des Antigens mit einem direkten Radioimmunassay erfordert jedoch noch die Entwicklung geeigneter Verfahren für eine wirksame Abtrennung und/ oder Denaturierung von Störsubstanzen.

\section{Introduction}

The excretion of kallikrein in urine has been reported to be altered in certain forms of hypertensive cardiovascular diseases (1). However, the physiological or pathological role of this hypotensive enzyme system in hypertension is not understood.

Kallikrein activity has been measured by its ability to hydrolyze certain acylated arginine esters or by its ability to form kinins from kininogen (2). However, the esterolytic assay lacks specificity and the proteolytic assay is subject to many variables often resulting in imprecise data. Moreover, the inhibitors of kallikrein and kallikreinlike enzymes, which are generally present in tissues and body fluids, can indeed interfere in the functional assays. Thus, a kallikrein-binding radioimmunoassay (RIA) may prove useful not only for the resolution of some of the debated issues $(3,4)$ but also for probing into the molecular mechanism of secretion of precursor and/or active forms of kallikrein in urine, lymph and plasma.
Recently Oza et al. (5) produced antibodies of rat urinary kallikrein. These antibodies produced rapid inhibition of kallikrein both in vivo and in vitro. Preliminary data on a sensitive component-binding RIA have been reported $(6,7)$. The present paper deals with the development of optimal conditions for the assay. In addition, the assay is employed in conjunction with the Ouchterlony technique to identify glandular kallikrein in plasma.

\section{Methods and Results}

Rat urinary kallikrein was isolated as described previously (5) by DEAE-cellulose, affinity (Trasylol-Sepharose) and Sephadex G-100 chromatography. Pure kallikrein was $\left[{ }^{3} \mathrm{H}\right]$-labelled with fluoro-2, 4-dinitro- $\left[3,5-{ }^{3} \mathrm{H}\right]$ benzene (New England Nuclear Corp., Boston, MA, U.S.A.) and purified by dialysis and Sephadex G-100 gel filtration (7). The purified, immunoreactive [ ${ }^{3} \mathrm{H}$ ]kallikrein had a specific radioactivity of $947.2 \mathrm{TBq} / \mathrm{mol}$ (25.6 Ci/mmol) (Packard Tri-carb scintillation counter with efficiency of about $60 \%$ ), and it was stored frozen in $0.05 \mathrm{~mol} / \mathrm{l}$ Tris-HCl buffer, pH 7.4, containing $1 \mathrm{~g} / 1$ bovine serum albumin (assay buffer) 
Although the RIA was standardized mainly with the $\left[{ }^{3} \mathrm{H}\right] \mathrm{kalli}-$ krein, the possibility of increasing the sensitivity of the assay by using [ ${ }^{125}$ I] kallikrein was investigated. Pure kallikrein was iodinated in $20 \mu \mathrm{g}$ batches with $37 \mathrm{MBq}$ carrier-free ${ }^{125}$ I (New England Nuclear Corp.) according to the procedure of Hunter \& Greenwood (8). Immunoreactive [ ${ }^{125}$ I]kallikrein was purified by Sephadex G-100 gel filtration as detailed in a prevous paper (7). The specific radioactivity was calculated to be $2.37 \mathrm{kBq} / \mu \mathrm{g}$ $(64 \mu \mathrm{Ci} / \mu \mathrm{g})$ or approx. 1 iodine atom per molecule of kallikrein.

\section{Antikallikrein}

Rabbit anti-rat urinary kallikrein serum was that reported by Oza et al. (5). A single batch of high-titer antiserum was used throughout these studies.

\section{Double antibody}

The initial supply of goat anti-rabbit immunoglobulin (IgG type) serum (double antibody) was purchased from Miles Laboratories, Inc., Elkhart, Ind. However, the potency of the commercial antiserum varied from batch to batch, requiring restandardization of the assay conditions. Therefore, the double antibody was raised in a goat and, once again, a single pool of high-titer anti-rabbit immunoglobulin (IgG) serum was used throughout these studies.

\section{Separation of free from antibody-bound $\left[{ }^{3} \mathrm{H}\right]$ kallikrein}

The formation of antigen-antibody conjugate was first assessed by the filtration of $\left[^{3} \mathrm{H}\right]$ kallikrein and antigen-antibody reaction mixtures on a Sephadex G-100 column $(1.5 \times \cdot 12 \mathrm{~cm})$. The column was equilibrated in the assay buffer and calibrated by filtration of $1.0 \mathrm{mg}$ Blue Dextran 2000 (Pharmacia Fine Chemicals, Piscataway, N.J.). Following this, approx. 4000 counts/min of $\left.{ }^{3} \mathrm{H}\right] \mathrm{kallikrein}$ was passed through the column.

The $\left[{ }^{3} \mathrm{H}\right]$ kallikrein emerged in a uniform peak at about two times the void volume of the column as shown in figure 1a. Nonetheless, a distinction could not be made between the control $\left(\left[{ }^{3} \mathrm{H}\right] \mathrm{kallikrein}\right.$ and non-immune serum) and experimental $\left(\left[{ }^{3} \mathrm{H}\right]\right.$ kallikrein and anti-kallikrein serum) incubation mixtures when they were passed through the same column (see fig. 1a). Perhaps the nonimmune and immune sera contained protein inhibitors of kallikrein (9).

In another experiment, aliquots of normal rabbit serum and antikallikrein serum were adjusted to $\mathrm{pH} 3.0$ with $1 \mathrm{~mol} / 1 \mathrm{HCl}$, allowed to stand for $30 \mathrm{~min}$ at $25^{\circ} \mathrm{C}$ and readjusted to $\mathrm{pH} 7.4$ with $1 \mathrm{~mol} / 1 \mathrm{NaOH}$ (acid pH treatment). Both the sera were then heated to $56^{\circ} \mathrm{C}$ for $3 \mathrm{~h}$ and centrifuged at $3079 \mathrm{~g}$ for $30 \mathrm{~min}$ (heat treatment). The supernatants (treated normal rabbit serum or anti-kallikrein) were used in appropriate dilutions.

As shown in figure $1 \mathrm{~b}$, a marked distinction was now obtained in the filtration profiles of the control and experimental reaction mixtures. As expected, the incubated reaction mixture of $\left[{ }^{3} \mathrm{H}\right] \mathrm{kallikrein}$ and normal rabbit serum emerged as a single peak at twice the void volume while the incubated reaction mixture of $\left[{ }^{3} \mathrm{H}\right] \mathrm{kallikrein}$ and antikallikrein emerged as two peaks (see fig. 1b). The first peak emerging with the void volume corresponded to the $\left[{ }^{3} \mathrm{H}\right] \mathrm{kallikrein}$-anti-kallikrein while the second peak emerg ing at twice the void volume corresponded to the unreacted $\left[{ }^{3} \mathrm{H}\right] \mathrm{kallikrein}$. In view of this, all of the sera employed in this study were given acid $\mathrm{pH}$ and heat treatment prior to their use in the RIA.

In a typical experiment, the anti-kallikrein was also tested directly and after acid and heat treatments for fraction of binding with approximately 4000 counts/min of $\left[{ }^{3} \mathrm{H}\right]$ kallikrein. In $1: 25,000$ dilution, untreated antibody showed 0.50 , and treated antibody

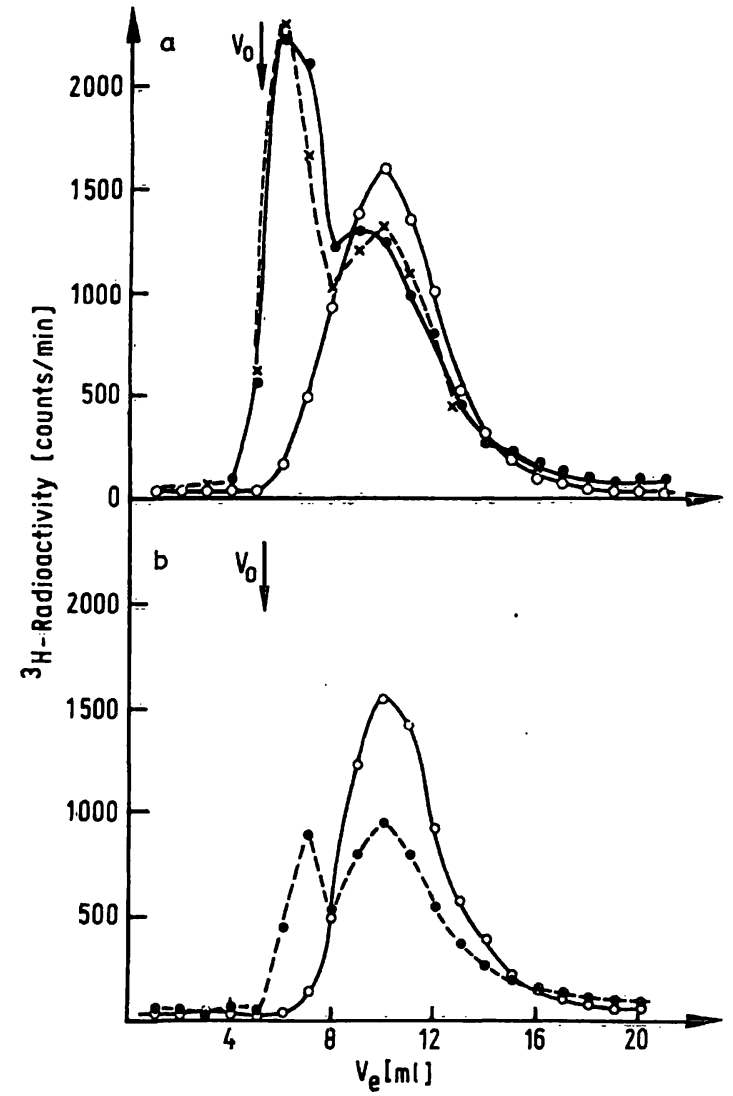

Fig. 1. Sephadex G-100 gel filtration of $\left[{ }^{3} \mathrm{H}\right]$ kallikrein (o) and of incubation mixtures of $\left[{ }^{3} \mathrm{H}\right]$ kallikrein with normal rabbit serum $(x)$ and anti-kallikrein serum (o) in the upper half ' $a$ ' of the figure. In the lower half ' $b$ ' are shown the elution profiles of the same incubation mixtures in which the normal and antikallikrein serum were used after acid $\mathrm{pH}$ and heat treatment as described in the text. The column was $1.5 \times 12 \mathrm{~cm}$; the void volume is shown by the arrow.

0.472 conjugation. Thus, the treated antibody had little or no effect on the formation of a workable conjugate in the radioimmunoassay.

\section{Optimum concentration of anti-kallikrein and double antibody}

The anti-kallikrein serum was adjusted to four different dilutions to obtain fractions of $0.70,0.50,0.30$ and 0.20 binding of $\left[{ }^{3} \mathrm{H}\right]$ kallikrein. Seven reactions were set up for each dilution of anti-kallikrein serum in which the double antibody was added in increasing amounts from 20 to $100 \mu \mathrm{l}$.

As shown in figure $2 \mathrm{a}, 20 \mu \mathrm{l}$ double antibody were found to be optimal for complete precipitation of $\left[{ }^{3} \mathrm{H}\right] \mathrm{kallikrein}$ anti-kallikrein conjugate when the initial binding was 0.48 (see reaction no. 2). As shown in figure $2 b$, the effective dilution of anti-kallikrein serum was found to be $1: 25000$ for a desirable initial binding of 0.48 . In the subsequent experiments, anti-kallikrein serum was therefore used in a final dilution of $1: 25000$, and the double antibody in a final dilution of $1: 30(20 \mu \mathrm{l}$ in $0.6 \mathrm{ml}$ tótal volume).

\section{Optimal time of first incubation .}

The fraction of maximal binding was studied as a function of time of incubation. 


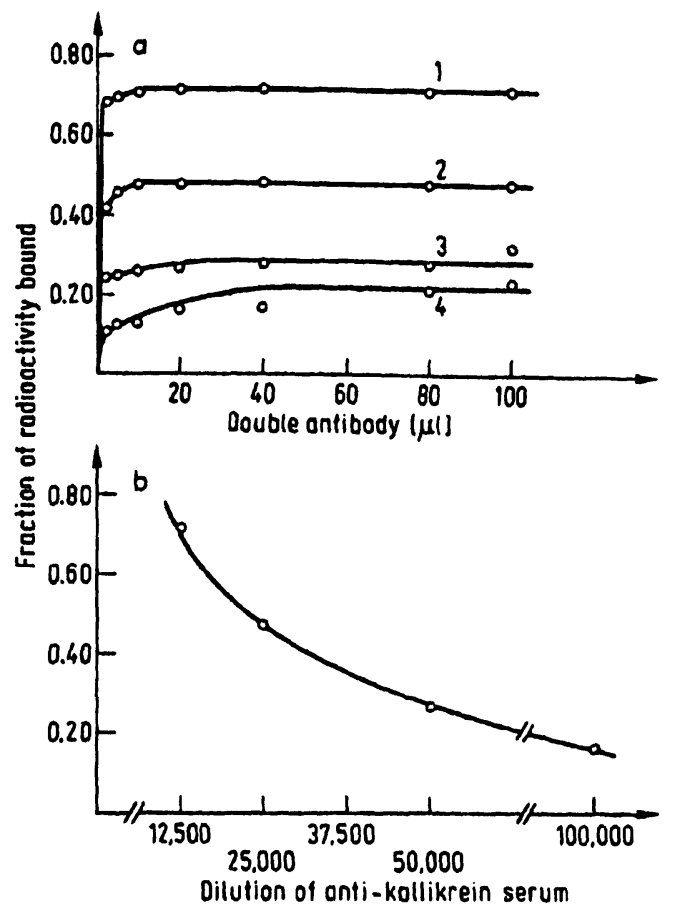

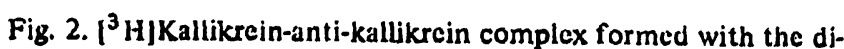
lutions $1: 25500$ (2), $1: 50000$ (3), and $1: 100000$ (4) of the antiserum. The antigen-antibody complex was precipitated with different amounts of double antibody. In reactions 1 and 2, the optimal concentration of the double antibody was found to be $20 \mu \mathrm{l}$ (inset a). The fraction of initial binding with different dilutions of anti-kallikrein serum is shown in inset ' $b$ '. The experiment was performed at $\mathrm{pH} 7.4$; the time of the first incubation was $2 \mathrm{~h}$ and that of the second incubation was $18 \mathrm{~h}$.

The data presented in figure 3 indicated that over 0.95 of binding occurred within $2 \mathrm{~h}$ of incubation of $\left[{ }^{3} \mathrm{H}\right] \mathrm{kalli}$ krein with the anti-kallikrein serum at $25^{\circ} \mathrm{C}$. In a similar study, the optimal time for second incubation, following the addition of double antibody, was found to be $18 \mathrm{~h}$ at $4^{\circ} \mathrm{C}$.

\section{Optimal pH}

The RIA was performed in the assay buffer adjusted to $\mathrm{pH} 7.0$, 7.4, 8.0 and 8.5.

As shown in figure 4, satisfactory displacement was obtained at $\mathrm{pH} 7.0-7.4$. In assays routinely performed at $\mathrm{pH} 7.4$ the coefficient of intra-assay variation $(n=6)$ was found to be $7.6 \%$. Furthermore, when a single urine was analyzed for 7 consecutive days, the kallikrein concentration was found to be $7.2 \pm 0.3 \mathrm{mg} / \mathrm{l}$ (mean \pm S.E.M.).

\section{Protocol:for the radioimmunoassay}

$\left[{ }^{3} \mathrm{H}\right]$ Kallikrein was suitably diluted in the assay buffer so as to contain approx. 4000 counts $/ \mathrm{min}$ in $0.1 \mathrm{ml}$. Anti-kallikrein serum was diluted $1: 5000$ in the assay buffer which in addition contained 1:4000 dilution of the treated normal rabbit serum for the enrichment of non-immune immunoglobulins. The renction mixture contained $0.1 \mathrm{ml} \mathrm{l}^{3} \mathrm{H}$ ) kallikrein (approx. 4000 counts/min), $0.1 \mathrm{ml}$ of a $1: 5000$ dilution of anti-kallikrein serum, unlabelled pure kallikrein (usually 5-200 ng), or the unknown sample, and the balance of buffer to a total volume of $0.5 \mathrm{ml}$. The reaction mixture was incubated $2 \mathrm{~h}$ at $25^{\circ} \mathrm{C}$, followed by addition of $100 \mu \mathrm{l}$ of $1: 5$ dilution of double antibody to each

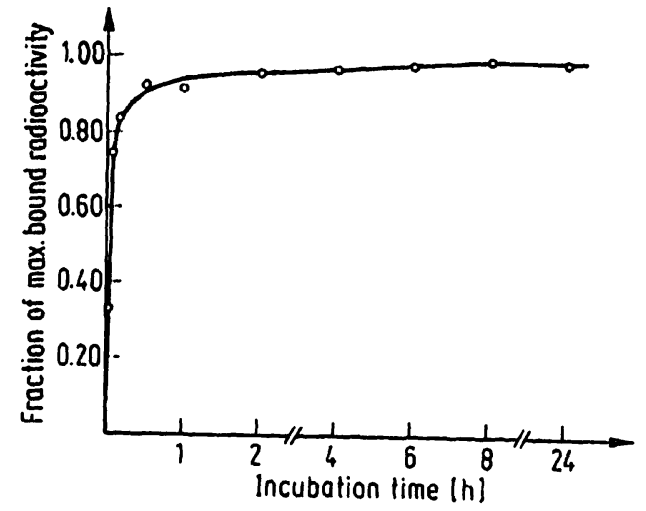

Fig. 3. The fraction of maximal binding shown at different times of the first incubation. The tine of the second incubation was kupt constant at $18 \mathrm{~h}$.

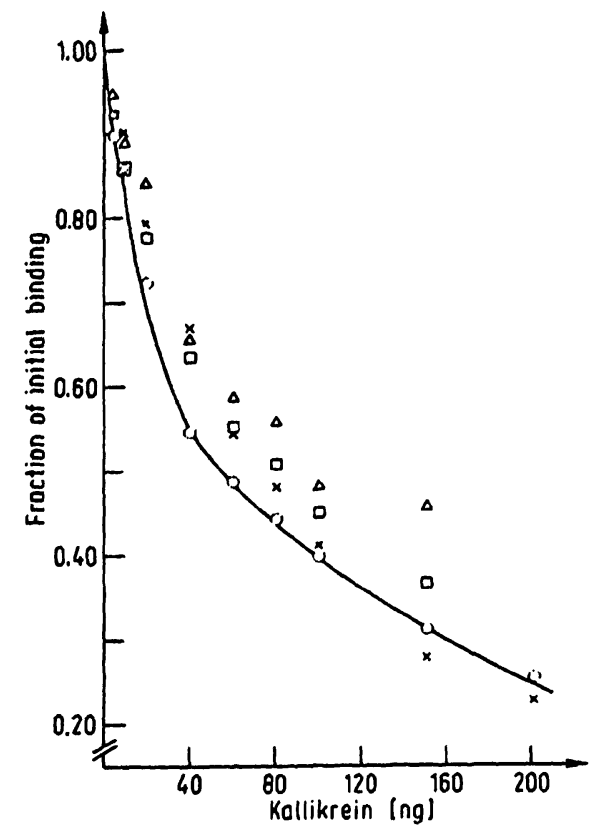

Fig. 4. The radioimmunoassay curve obtained at pH 7.4 (o) compared with experimental valucs obtained at pH $7.0(x)$ $8.0(\square)$, and $8.5(\Delta)$.

tubc. The assay tubes were furthcr incubated $18 \mathrm{~h}$ at $4^{\circ} \mathrm{C}$; the resulting precipitate of $\left[^{3} \mathrm{H}\right]$ kallikrein-anti-kallikrein-double antibody complex was collected by centrifugation at $3079 \mathrm{~g}$ for $30 \mathrm{~min}$ in a refrigerated centrifuge. The supernatant $(0.3 \mathrm{ml})$, containing frec $l^{3} \mathrm{H} \mid$ kallikrcin, was mixed with $10 \mathrm{ml}$ of solubilizer [18\% BBS-3 (Beckman Instruments, Inc., Fullerton, Calif.), $42 \mathrm{ml}$ liquiflour Q.S. made up to 1 liter with toluene) and counted for at least $10 \mathrm{~min}$. Tolal counts were determined by substituting anti-kallikrcin serum with normal rabbit scrum. Duplicate estimations were made and the unknown sample was interpolated from a standard plot of fraction of initial binding versus the amount of added kallikrein. The standard curve was constructed by a computer program which plotted fraction of initial binding versus the a mount of added kallikrein (10).

\section{RIA with $\left[{ }^{125}\right.$ I] Kallikrein}

The assay conditions were identical to those already described, excopt that the anti-kallikrein serum was used in a dilution of $1: 40000$, and the first incubation was performed for $4 \mathrm{~h}$. 
The standard plot, in figure 5, enabled determination of 1 to $10 \mathrm{ng}$ of kallikrein. Furthermore, $1 \mathrm{ng}$ gave a fraction of initial binding of 0.89 (fig. 5) as opposed to $10 \mathrm{ng}$ that was required to obtain a fraction of initial binding of 0.90 (fig. 4) in the case of $\left[{ }^{3} \mathrm{H}\right]$ kallikrein. Thus, as expected, the sensitivity was increased approximately ten fold by using $\left[{ }^{125} \mathrm{I}\right]$ kallikrein as a tracer.

Forty-six rat urine samples were analyzed for kallikrein by the direct RIA and for kinin-generating activity by a kinin RIA (11). A correlation coefficient of 0.81 was obtained (7).

\section{Identification of glandular kallikrein-like antigen in plasma}

Blood was collected by decapitation of rats (normal or 24 hours after bilateral nephrectomy) in 200 units of heparin. After centrifugation, the plasma samples of individual rats were kept frozen.

The RIA was employed to test normal rat plasma either directly, after serial dilutions (e.g. $1: 2,1: 4,1: 8 \ldots$ etc.), or after acidification and heat denaturation, as described in a previous section.

Normal rat plasma was capable of displacing the antigenantibody complex, but the displacement curve (see figure 6) was not parallel to the standard curve. After a serial dilution of $1: 1024$, the antigen concentration was increased almost 20 fold. Although dilution invariably caused an increase in the concentration of radioimmunoassayable kallikrein, the extent of dilution differed from one sample to the other. After acidification and heat denaturation of normal rat plasma, the antigen concentration was reduced by almost $90 \%$. This treatment was therefore not suitable for selectively denaturing interfering substance(s). Although dilution of normal plasma appeared promising, further efforts to quantitate plasma antigen were defferred until such time as a uniform technique could be devised for physical separation or selective denaturation of the interfering substance(s).

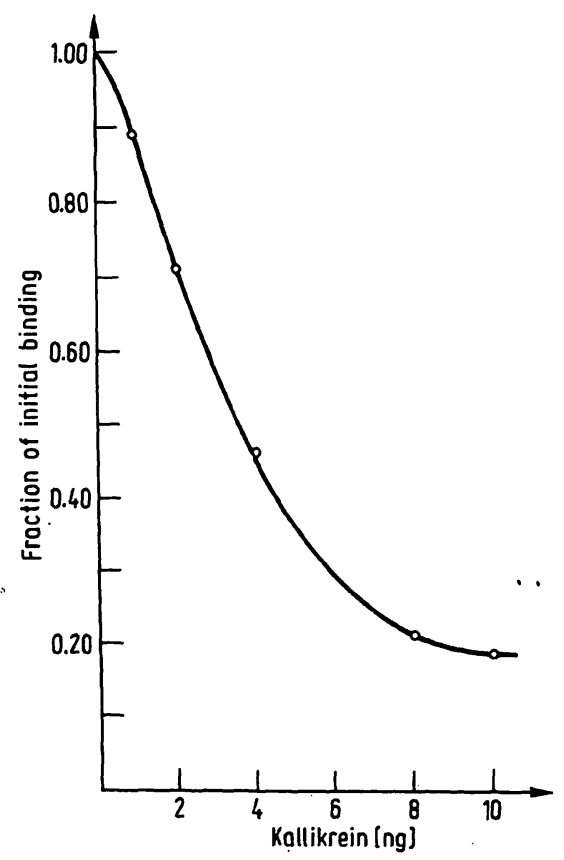

Fig. 5. A standard radioimmunoassay curve using $\left[{ }^{3} \mathrm{H}\right]$ kallikrein as a radiolabelled antigen.

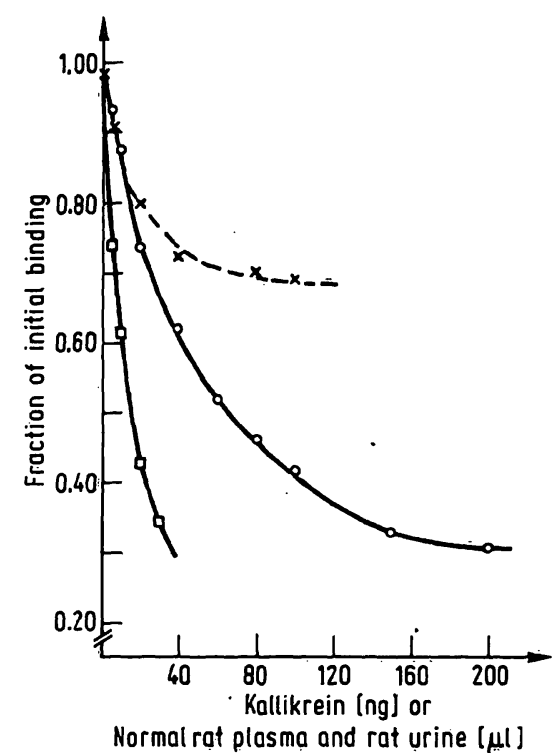

Fig. 6. Comparison of the displacement profiles of rat plasma $(x)$ and rat urine with the standard plot (o).

Owing to the above limitation stated, immunodoublediffusion (12) was employed to qualitatively identify the antigen in normal and nephrectomized rat plasma. The center well contained undiluted rabbit anti-rat urinary kallikrein serum and peripheral wells contained either normal rat plasma or nephrectomized rat plasma in a range of zero to 2048 fold dilutions.

A distinct precipitation band (line of identity) was obtained when the normal rat plasma was either undiluted or diluted $1: 2$. In the case of nephrectomized rat plasma, a much stronger line of identity was obtained when the plasma was diluted $1: 16$ to $1: 32$. Using nephrectomized rat plasma, it was expected that the precipitin band would disappear if the antigen was secreted by the kidney. On the contrary, the concentration of the antigen was enhanced, suggesting that kidney may be involved in the filtration of glandular kallikrein secreted into the circulation.

As shown in figure 6, high displacements were obtained with $5-30 \mu$ l of rat urine. Normal rat urine contains kallikrein in the concentration of $5-7 \mathrm{mg} / 1$ urine. Thus, the nonparallelity of urine aliquots, in this experiment, was due to a concentration which was about five fold higher than the range of the standard curve. In other experiments, a perfect parallelity was in fact obtained when the urine sample was diluted $1: 5$ or $1: 10$ in the RIA buffer.

\section{Discussion}

Since the initial recognition by Elliot \& Nuzum (13) of the suppression of urinary kallikrein in essential hypertension, many reports have appeared which either confirmed (14) or extended (1) this inexplicable finding. Recently, evidence has been adduced $(14,15)$ to suggest the role of kallikrein in diureșis and natriuresis. Nonetheless, it remains to be resolved whether the alterations in the excretion of this enzyme are deleterious, beneficial, or incidental. It also remains to be determined whether the implications of kallikrein release are local ór are systemic. 
It may be possible to resolve some of these issues with the use of a component-binding assay.

In addition to forming an antigen-antibody conjugate, the radiolabelled kallikrein was found to bind with a protein component of the rabbit serum (see fig. 1). The nature of the component is not known at present, but normal serum is known to contain certain inhibitors (16). Since serum inhibitors of kallikrein can be denatured by acid $\mathrm{pH}$ and/or heating at $56{ }^{\circ} \mathrm{C}(9)$, it is conceivable that the unspecific binding, encountered in the present study, was due to one of the inhibitors.

It is evident from the present data that the anti-kallikrein serum employed in the present study was of a higher quality. In $1: 25000$ dilution (fig. 2), the antiserum gave 0.48 binding with radiolabelled enzyme. Almost all of this binding occurred in $2 \mathrm{~h}$ of incubation (fig. 3). The consistency of the displacement curve obtained at $\mathrm{pH}$ 7.0-7.4 (fig. 4) was indeed of help in the measurement of kallikrein at the physiological $\mathrm{pH}$ of rat plasma.

In immunodoublediffusion tests (5), the anti-kallikrein serum was found to react with rat urine and homogenates of salivary gland, pancreas and kidney, but not with bovine trypsin, or dog or human urine. Recently Proud et al. (17), using a direct radioimmunoassay, showed that salivary, urinary and pancreatic kallikrein, and pancreatic prekallikrein have identical immunological behaviour.

The direct immunoassay of an enzymic protein is particularly advantageous since it utilizes the antigenic property of the enzyme and not the affinity of the enzyme for its substrate or inhibitor. Thus, theoretically it should be possible to determine the concentration of the enzyme in the presence of its inhibitor as long as the inhibitor is not large enough to bury antigenic determinants. In the case of a trypsin radioimmunoassay (18), serum inhibitors were found not to interfere in the determination of circulating trypsin. In the present study, rat urine samples were analyzed directly for kallikrein concentration because no apparent differences were found between dialyzed and undialyzed samples.

In a few experiments, the first incubation of radiolabelled kallikrein and antikallikrein was performed for $18 \mathrm{~h}$ instead of $2 \mathrm{~h}$ with no obvious improvement in the profile of the standard plot. Furthermore, it was evident that the radioimmunoassay could be performed with $\left[{ }^{125} I\right] \mathrm{kalli}-$ krein or $\left[{ }^{3} \mathrm{H}\right] \mathrm{kallik}$ rein depending upon the requirement for a higher sensitivity (see fig. 5) or durability of the enzyme. The biological relevance of the assay was demonstrated by a high correlation of 0.81 between the present direct assay and a functional assay (7).

There is evidence in the literature which suggests that glandular kallikrein may be released in the systemic circulation (19-21). More recently, Rabito et al. (22) and Fink et al. (23) have adduced immunological evidence for the presence of glandular kallikrein in plasma. However, contrary reports. $(24,25)$ have indicated that glan- dular kallikrein is not normally found in the plasma. The objective of the present work was to qualitatively identify such an antigen if it is indeed detectable by immunological and/or radioimmunological techniques. The preliminary experiments, reported here, indicated that glandular kallikrein is indeed present in the normal rat plasma. The concentration of this antigen is increased 24 hours after nephrectomy suggesting that kidneys may be able to filter such an antigen. The question of whether the antigen is radioimmunoassayable is not adequately answered by the present experiments. The displacement profile with plasma antigen was not parallel to the standard curve (see fig. 6). Such a displacement may be due to interference with the availability of the antigenic determinants of a specific antigen. The fact that the concentration of this antigen was increased by dilution is compelling and it tends to support a thesis that the displacement was due to a specific antigen (glandular kallikrein) which was partially masked by interfering substances of the plasma. Nonetheless, a final identification must await isolation and characterization of the antigen. Recently, Geiger et al. (27) have acheived isolation of glandular kallikrein from human plasma.

The significance of glandular kallikrein in plasma is not. known. However, it has been reported that plasma contains $10 \%$ of a high molecular weight kininogen and $90 \%$ of a low molecular weight kininogen (26). Thus, if glandular kallikrein should be secreted into the circulation, a large amount of its preferred substrate (low molecular weight kininogen) is indeed available. Nonetheless, the secreted enzyme must compete for the substrate in the presence of a large amount of interfering substance(s), which are normally present in the plasma (16).

In conclusion, a detailed account of the development of a direct RIA of rat urinary kallikrein has been presented. Using this assay and the immunodoublediffusion technique, data have been obtained which suggest the release of glandular kallikrein in plasma. Furthermore, preliminary evidence is suggestive that the kidneys may be able to filter glandular kallikrein which is released in the circulation. The findings are in agreement with the data of Fink et al. (23) who investigated renal filtration of pig pancreatic kallikrein in dogs.

\section{Acknowledgements}

A major portion of this work was done in the Hypertension Re search Laboratory, Department of Medicine, Henry Ford Hospital, Detroit, Michigan. I am grateful to Dr. Oscar A. Carretero, $M$. D., for introducing me to this exciting research, for sharing many common goals during our affiliation, and for his consent to publish this work. Expert technical assistance of Mr. $V . M$. $A$ min and $R$. Gandolf $i$ is acknowledged with thanks. Thanks are also due to Dr. Sam Yanari for $\left[{ }^{3} \mathrm{H}\right]$-labelling of kallikrein.

The manuscript was finally prepared during the support provided by Grants HL 23304, HL 18318 and AM 21683 from the National Institutes of Health. 


\section{References}

1. Margolius, H. S., Geller, R. G., Pisano, J. J., \& Sjoedsma, A. (1971), Lancet II, 1063-1065.

2. Trautschold, I. (1970), Handb. Exp. Pharmacol. 25, 52-81.

3. Geller, R. G., Margolius, H. S., Pisano, J. J., \& Keiser, J. R. (1972) Circ. Res. 31, 857-861.

4. Adetuyibi, A. \& Mills, I. H. (1972), Lancet II, 203-207.

5. Oza, N. B., Amin, V. M., McGregor, R. K., Scicli, A. G., \& Carretero, O. A. (1976), Biochem. Pharmacol. 25, 1607-1612.

6. Oza, N. B., Amin, V. M., Gandolfi, R., Yanari, S., \& Carretero, O. A. (1976), Fed. Proc. 35, 693.

7. Oza, N. B. (1977), Biochem. J. 16.7, 305-307.

8. Hunter, W. M. \& Greenwood, F. C. (1962), Nature 194, 495-496.

9. Vogel, R. \& Werle, E. (1970), Handb. Exp. Pharmacol. 25, 213-249.

10. Rodbard, D., Rayford, P. L., Cooper, J. A., \& Ross, G. T. (1968), J. Clin. Encrinol. Metab. 28, 1412-1418.

11. Carretero, O. A., Oza, N. B., Piwonska, A., Ocholik, T., \& Scicli, A. G. (1976), Biochem. Pharmacol. 25, 2265-2270.

12. Ouchterlony, O. (1949), Acta Path. Microbiol. Scand. 26, 507-512.

13. Elliot, A. H. \& Nuzum, F. R. (1934), Endocrinol. 18, 462-474.

14. Croxatto, H. R. \& San Martin, M. (1970), Experientia 26, $1216-1217$.

15. Mills, I. H. \& Ward, P. E. (1975), J. Physiol. 246, 695-707.

16. Harpel, P. C. (1971), J. Clin. Invest. 50, 2084-2090.
17. Proud, D., Bailey, G. S., Nustad, K., \& Gautwik, K. M. (1977), Biochem. J. 16.7, 835-838.

18. Temler, R. S. \& Felber, J. P. (1976), Biochim. Biophys. Acta 445, 720-728.

19. Roblero, J., Croxatto; H., Garcia, R., Corthorn, J., \& DeVito, E. (1976), Am. J. Physiol. 231, 1383-1389.

20. Fink, E., Seifert, J., Guttel, C. (1978), Z. Anal. Chem. 290, 183-188.

21. Nustad, K., Orstavik, T. B., Gautvik, K. M., \& Pierre, J. V. (1978), Gen. Pharmacol 9, 1-9.

22. Rabito, S., Amin, V. M., Scicli, A. G., \& Carretero, O. A. (1979), Fed. Proc. 38, 686.

23. Fink, E., Geiger, R., Witte, J., Biedermann, S., Seifert, J., \& Fritz, H. (1980) In: Enżymatic release of vasoactive peptides (Gross, F., \& Vogel, H. G., eds.) Raven Press, New York, P. 101.

24. Pisano, J. J. (1875), In Pĩoteases and Biological Control, Cold Spring Harbor Laboratory, Cold Spring Harbor, N. Y., 199-222.

25. Vinci, J. M., Gill, J. R, Bowḍen, R. E., Pịsano, J. J., Izzo, J. L., Radter, N., Taylor, A. A., Zusman, R. M., Bartter, R. C., \& Keiser, H. R. (1978), J. Clin. Invest. 61, 1671-1682.

26. Hashimoto, K, Wanka, J., Kohn, R. N., Wilkens, J. J., Steger, R., \& Back, N. (1976), Adv. Exp. Med. Biol. 70, 245-254.

27. Geiger, R., Chlausnitzer, B., Fink, E., \& Fritz, H. (1980), Hoppe-Seyler's Z. Physiol. Chem. 361, 1795-1803.

Narendra B. Oza, Ph. D.

Asșociate Research Professor of Medicine and Associate Professor of Biochemistry Boston University School of Medicine University Hospital

75 East Newton Street

Boston, Mass. 02118

U.S.A. 